\title{
HIV-2 Antibody Measurement
}

National Cancer Institute

\section{Source}

National Cancer Institute. HIV-2 Antibody Measurement. NCI Thesaurus. Code C74715.

The determination of the antibody reaction of a sample to the HIV-2 virus. 